\title{
Hematological and biochemical changes in a Phrynops geoffroanus (Schweigger, 1812) population in response to environmental stressors
}

\author{
M.I.A. Silva \\ 2011. Programa de Pós-Graduação em Genética, Instituto de Biociências, \\ Letras e Ciências Exatas, Universidade Estadual Paulista "Júlio de Mesquita \\ Filho", São José do Rio Preto, SP, Brasil. Msc thesis. Orienting Prof.: Claudia \\ Regina Bonini Domingos. Co-orienting Prof.: Eduardo Alves de Almeida \\ DOI $10.4238 /$ vol10-2ta037
}

Turtles are among the most endangered vertebrate groups, and the main threats to populations are environmental pollution and habitat degradation. The species Phrynops geoffroanus, popularly known as "Geoffroy's side-necked turtle", has proliferated in polluted environments, where adverse conditions could influence their living habits and physiological condition. Studies that monitor the effects of environmental pollution are key to understanding the species' biology and designing effective conservation strategies. Thus, the analysis of hematological and biochemical parameters has been shown to be important in assessing the health of wild animals and risks for the animal and ecosystem. This study aimed to assess the environmental influence on the physiology of a $P$. geoffroanus population through the evaluation of antioxidant status and responses to environmental stressors, compared to specimens from a place under controlled conditions. Blood samples of 60 specimens were collected, 30 from the Felicidade Stream, polluted environment, within the city of São José do Rio Preto, and 30 from the "Reginaldo Uvo Leone" breeding farm, Tabapuã, SP, a place under controlled conditions, whose samples constituted the control group. They were evaluated by hemogram and by determining thiobarbituric acid reactive species (TBARS), Trolox-equivalent antioxidant capacity (TEAC) and the activities of the antioxidant enzymes catalase and glucose-6-phosphate dehydrogenase (G6PDH). There was a wide variation in hematological parameters of $P$. geoffroanus from the urban environment. The red blood cell count and hemoglobin values were significantly less than those observed in animals from the breeding farm $(\mathrm{P}=0.0004 ; \mathrm{P}$ $=0.0371$, respectively). There was a significant increase in the number of thrombocytes $(\mathrm{P}<$ $0.0001)$ and leukocytes $(\mathrm{P}<0.0001)$ in the animals from Felicidade Stream. The stress indices were similar between the two groups $(\mathrm{P}=0.4077)$. TBARS levels showed the cytotoxic potential of compounds in the urban environment, whose animals had elevated levels of lipid peroxidation $(\mathrm{P}<0.0001)$, despite showing a response to environmental damages with increase 
in antioxidant capacity, as demonstrated by the TEAC assay $(\mathrm{P}=0.0207)$. The lower catalase enzyme activity noted in individuals from the urban environment $(\mathrm{P}=0.000184)$ could be due to the presence of inhibitory compounds. On the other hand, G6PDH activity was higher (P $=0.002962$ ), where this enzyme acts in the generation of NADPH, which is used in several detoxification pathways. We conclude that environmental contamination can increase oxidative damages and generate physiological changes in this species. These data are very useful for the conservation of $P$. geoffroanus and turtles in general, and confirm that these techniques are effective in monitoring natural regions and that $P$. geoffroanus can serve as an environmental contamination bioindicator.

Key words: Hematology; Ecotoxicology; Lipid peroxidation; Antioxidant defenses; Phrynops geoffroanus 